\title{
Kniha o lyrice jako koncepce, výzva a malé americko-české srovnání
}

\author{
Ivo Pospíšil (Brno)
}

Jonathan Culler: Teorie lyriky. Studia poetica. Praha: Univerzita Karlova, nakladatelství Karolinum, 2020. 459 s. ISBN 978-80-246-4456-1, ISBN 978-80-246-4457-8 (pdf).

Autor (roč. 1944) je světově proslulý literární teoretik známý i u nás, mimo jiné v překladu vyšel populární Krátký úvod od literárni teorie (Brno: Host, 2002, pův. Literary Theory: A Very Short Introduction, Oxford University Press 1997). Dalo by se říci, že Culler je jednak velký seznamovatel anglofonního světa, a tím i světa jako takového, s klíčovými směry literární vědy (strukturalismus j francouzského ražení, dekonstrukce, sémiotika, teorie prózy aj.). ${ }^{1}$ Profesor na Cornellově univerzitě, rodák z Clevelandu, student na Oxfordu a Harvardu. Postupně převzal po jiných anglicky píšících literárních vědcích roli poučeného popularizátora a syntetika, současně však, jako třeba vídeňský rodák a náš krajan René Wellek, přináší

1 Začalo to knihou o G. Flaubertovi (Flaubert: The Uses of Uncertainty. Elek Books London, Ithaca: Cornell University Press, 1974; 2nd revised edition: Cornell University Press, 1985) a pokračovalo to publikacemi o jevech, s nimiž se Culler sám vyrovnával a reagoval na ně (strukturalismus, sémiotika, poststrukturalismus a dekonstrukce: Structuralist Poetics: Structuralism, Linguistics, and the Study of Literature. London: Routledge and Kegan Paul; Ithaca: Cornell University Press, 1975; revised edition Routledge Classics, 2002. Saussure/Ferdinand de Saussure London: Fontana Modern Masters; Harvester, Brighton 1976; New York: Penguin, 1977; second revised edition, Ithaca: Cornell University Press, 1986; London: Fontana, 1987. The Pursuit of Signs: Semiotics, Literature, Deconstruction. London: Routledge and Kegan Paul, Cornell University Press, Ithaca, 1981; revised edition, Routledge Classics, Routledge, 2001, Cornell University Press, 2002. On Deconstruction: Theory and Criticism after Structuralism. Ithaca: Cornell University Press, 1982; London: Routledge, 1983, později šlo o naratologii (Narrative Theory: Critical Concepts in Literary and Cultural Texts. Ed. by Mieke Bal. London - New York: Routledge, 2004), na konci devadesátých let minulého století vznikly dva svazky o kritických koncepcích postmodernismu (Postmodernism: Critical Concepts, 1-2. London: Routledge, 1998). nové koncepce tím, že se pro sebe seznamuje s těmito jevy přicházejícími odjinud a snaží se je konfrontovat s vlastními tradicemi a představami a najít nové průniky a „okna“ do jiných směrů. Takto je koncipováno v podstatě vše, co Culler napsal, včetně této knihy z roku $2015 .^{2}$

Po všech těch knihách přeložených do řady jazyků, včetně češtiny, kde máme však jen torzo Cullerových spisů, přišla na řadu lyrika. Sám pojem a jeho pojetí se v různých národních prostředích liší: třeba v němčině se „die Lyrik“ vztahuje často nejen $\mathrm{k}$ neepické, nesyžetové poezii, ale také $\mathrm{k}$ verši jako takovému, původně spojenému s hudbou (lyra). „Dichtung“ se vztahuje nejen k básnění, ale $\mathrm{k}$ umělecké tvorbě jako takové, „die Poesie“ jsou verše, ale i umělecké dílo literární, „der Dichter“ je primárně básník, ale také umělec jako takový. V angličtině a češtině takové široké možnosti výkladu nemáme, ale někdy se i tu používá poezie nebo básník v přeneseném smyslu jako slovesný tvưrce. Lyrikou myslí Culler poezii v dnešním slova smyslu: zejména anglicky psaná literatura nezná dnes př́liš epiku a lyrickoepické struktury (když Culler píse o pokusech o „objektivizaci“ lyriky, myslí tím asi Browningův cyklus The Ring and the Book, 1868-69) nebo mohl uvést ze stejné literatury a dokonce viktoriánského období Alfreda Tennysona s jeho cyklem Idylls of the King, tedy Královské idyly, 1859, 1885), cyklem dvanácti narativních básní, jak Angličané nazývají lyrickoepické básně blízké ruské poemě (poema, z lat. poema = báseň). I v ruštině

2 CULLER, Johathan: Theory of the Lyric. Cambridge: Harvard University Press, 2015. 
používal slavný kritik V. G. Bělinskij slovo „básník“ („poet“) ve smyslu spisovatel obecně: pro něho byl takovým „básníkem“ třeba Gogol.

Culler napsal k českému překladu svého díla zvláštní předmluvu a jak jinak, když českému, tak píše o strukturalismu, o němž naspal disertaci, i když se týká - nehledě na silný propagační impakt pražské školy zprostředkovaný Romanem Jakobsonem - víceméně francouzského strukturalismu. Ostatně Jan Mukařovský přednášející na sorbonnské slavistice o strukturalismu roku 1946, jak se traduje, zůstal nepochopen, málokdo to znal a on sám byl takřka auctor ignoratus; pražská škola byla objevována až od šedesátých let minulého století a mimo západní Evropu a zejména USA (kde se o to zasloužili Jakobson a Wellek, ale také známá kniha Josefa Vachka ${ }^{3}$ ), např. antologie českého strukturalismu vychází v Dánsku známém svou glosematickou školou až na počátku sedmdesátých let. ${ }^{4}$ Ostatně Jakobsonovy vztahy k ní a jejím osobnostem jsou notoricky známé a u jednoho z nich (Viggo Brøndal, 1887-1942) po svém útěku z Protektorátu Böhmen und Mähren na kodaňském Radničním náměstí (Rådhupladsen) bydlel, jak dokládá jeho korespondenční lístek uchovávaný v Archívu Masarykovy univerzity v Brně. Takže je ta „česká“ předmluva takovou úklonou potenciálnímu českému čtenáři.

To, že autor vychází z anglosaské tradice, náležející k tzv. západnímu kánonu, tedy k tradici klasické (řecko-římské), italské, francouzské a anglické, když k tomu ještě připočteme poměrně pozdní vrcholy literatury německé a dál už nic. Nicméně i to je dost, aby mohl naplnit svůj cíl, jímž není dosažení vyšší komplexity, jak nám to slovy překladatele autor sděluje, ale „zaměrit se na některé zvlášt poutavé básně v tradici západni lyriky, aniž by pro ně podával nové interpretace“ (s. 14). Nakolik je např. starořecká lyrika západní, opravdu nevím, ale že byla na tzv.

3 A Prague School Reader in Linguistics. Ed. Josef Vachek. Edition Indiana University Studies in the History and Theory of Linguistics. Bloomington: Indiana University Press, 1964.

4 Tjekkisk strukturalisme - en antologi. Ed. Christian Kock. København, 1971.
Západě recipována, je známo. Těch jmen, jimž autor věnuje své acknowledgements, jsou desítky, přesně podle tradice. $\mathrm{Z}$ toho ovšem vysvítá, že koncepce lyriky vyrůstala $\mathrm{z}$ různých univerzitních přednášek a toto navrstvování je viditelné i v tomto vydání, aniž by to jakkoli snižovalo razanci a přesvědčivost výkladu. Nevím, zda má autor pravdu, když tvrdí, že „lyrika kdysi bývala ohniskem literárniho prožitku a literárního vzdèláni; zastinil ji však román - zčásti možná proto, že nemáme žádnou vyhovujici teorii lyriky“ (s. 18). Zaprvé nevím, proč by měla být lyrika ohniskem literárního vzdělání, když jde primárně o ústní projev spojený s hudbou a tancem, samozřejmě s magií a mýtem, a teprve poté zapsaný - a román je věc vskutku literární, psaná, ale také básnická a někdy i lyrická, ale hlavně syžetová, přičemž nemyslím, že by teorie románu nějak přispěla jeho čtenářské konzumaci - a to by mohlo platit i o lyrice. Viníkem neuspokojivého stavu, jenž se Culler rozhodl napravit, je podle něho př́lišný historismus valné části literární kritiky (rozuměj: vědy, s. 19): ukazuje, kterak měla lyrika jiné prezentace v antickém Řecku a jiní v alžbětinské Anglii. Jisté a u něho přirozené sklony $\mathrm{k}$ anglosaské tradici, napřr. anglické renesanci, jsou zřejmé již od úvodu - leckde je implicitně i explicitně zřejmé, že podle anglických univerzitních tradic jsou právě moderní Anglosasové největšími dědici antické poetiky a rétoriky a antického básnictví: nutkavě se vrací alžbětinská Anglie s jejími antickými vzory. Otevřeně rezignuje na to, aby ukázala hranice a tím i podal definici lyriky, i když ví, že lyrika se neomezuje jen lyrikou, ale proniká i do jiných žánrů: „Východiskem úvahy mi je soubor lyrických básni, jež jsou v rámci západni tradice výsostně kanonické a u nichž se snažím stanovit jejich nejuýrazněšsi rysy“ (s. 22). Proto stručně komentuje a uvádí strukturu své knihy (prezentace základních vlastností lyriky, pojem lyriky jako žánru, hodnocení různých konceptů lyriky). Následují další výklady v dalších kapitolách včetně poslední sedmé kapitoly, kde se probírá angažovanost lyriky a uvádějí se tři př́klady vývoje od antiky, k renesanci a romantismu, aby se autor v závěru dotkl Adornovy dialektiky a ideologie. Autor českého doslovu 
Josef Hrdlička je nucen přece jen na samém konci knihy připomenout i jiné kultury a literatury než tzv. západní. Tvrzení, že „česká poezie/ lyrika stoji na společných europských základech a že v tomto směru Cullerova Teorie lyriky vypovídá také o české poezii“, je sice uklidňující, ale není zcela pravdivé a to si autor doslovu uvědomuje, nebot na samém konci svého textu uvádí: „Podobná kniha napsaná v Čechách [snad i na Moravě nebo ve Slezsku, ale nevím - pozn. I. P.], v Polsku nebo $v$ Rusku by jistě vypadala jinak, ale zároveñ by se obracela $k$ něčmu společnému, snad by se dalo říci, $\check{z}$ by predstavovala pohled na tentýž kontinent, jen situovaný do jiné oblasti“ (s. 437-438). Hic Rhodus hic salta, chtělo by se dodat s tím, aby už brzy vznikla taková práce jako důležitý doplněk a současně protipól Cullerovy fundamentální knihy. Cullerovou metodou je indukce, ostatně tradiční anglosaský postup ve filozofii jdoucí až k Francisu Baconovi. V první kapitole rozebírá devět básní, na prvním místě Sapfinu jedinou cele dochovanou báseň Óda na Afroditu, v níž autor spatřuje prvopočáteční model lyriky jakožto informaci a událost. Dalším je Quintus Horatius Flaccus a jeho báseň v originále a překladu. Právě zde je vhodná zmínka o tom, že překladatel Martin Pokorný citlivě vybral české překlady, jež následují po originálním znění básní, v př́ípadě nutnosti je pak stejně citlivě upravil. Následuje Petrarca a čítanková Goethova Růžičcka. I zde - i ve srovnání se Sapfó - nacházíme komplexní strukturu (oslovení, rituální aspekt, prezentace a performativnost - s. 42). Podobně Leopardi a jeho Nekonečno, Baudelaire, jenž lyriku přenáší do městské ulice (Jedné kolemjdouci), Lorca, William Carlos Williams, Ze „čtyr parametrů " vybíráme alespoň snahu lyriky být událostí, nikoli jejím zpodobením (s. 55). Druhá kapitola Lyrika jako žánr je podle mého soudu nejvíce diskusní. Culler nepatří k těm, kteří by se dali důležitostí literárních žánrů „rozhodit“. Cullerův náhled na teorii žánrů neodpovídá takřka ničemu z toho, co teorie žánrů a koneckonců ani genologie jako samostatná disciplína postulovaly posledních padesát let; proto se mi nelíbí ani označení lyriky za žánr. Culler to vidí takto: „Problém nejistého žánrového postaveni lyriky je podle všeho předevšim důsledkem faktu, že Aristotelés prri rozboru mimetické poezie lyriku nepojal jako jeden z hlaunich literárnich druhü, prestože byl s formami řcké lyriky dobře obeznámen a v Rétorice z ni cituje mnoho přikladü“ (s. 71).

Jako by to nepřímo dokládalo nechut Anglosasů k spekulacím, a dokonce i teoretiků k přiliš obecným teoriím, tedy $\mathrm{k}$ teorii jako $\mathrm{k}$ něčemu svrchovaně obecnému, a často tedy empiricky neuchopitelnému. Na př́kladu dalších klasických básní (např. Horatius, Catullus) ukazuje na přenášení řeckých modelů do římských básní; podobným „bočním ziskem“ autorových úvah je Petrarca a trubadúrská lyrika a spor, který se rozhořel v 16 . století mezi lyrikou, jako pěstovali třeba Villon nebo Charles d'Orléans, v střetu s klasickým modelem, jenž překvapivě představoval i sonet, zejména Petrarcovou zásluhou, jíž se stal klasickým, tedy do jisté míry normou, všeobecně respektovaným a žánrem hodným napodobování; podobně vidí situaci lyriky v Anglii, jak ji vyjadřuje Philip Sidney v posmrtně vydané Defence of Poesie/Poesy nebo, jak se někdy uvádí, An Apology for Poetrie (napsáno asi 1580, vydáno 1595). V průběhu staletí soupeří lyrika v osvobozené podobě s různými experimenty, mj. spojenými s úsilím o její objektivizaci (Robert Browning, s. 100). V „žánrových“ partiích nemůže Culler nenarazit na "protižánrové“ smýšlení Paula de Mana. Uvádí básně Ch. Baudelaira Correspondances, tedy Spojitosti (snad jsou pořád případnější nezvalovské Souvztažnosti) nebo Posedlost. Nakonec po zmínce o Reném Wellkovi se vrací idea lyriky jako žánru z toho pohledu, že nemáme lepší možnost (s. 111) $)^{5}$. A následuje silnější vyjádření: „Žánrové koncepty tohoto typu zůstávaji nezbytným nástrojem a možná i hlavním polem literární historie: pokud je literatura něćm víc než jen sledem jednotlivých dèl, pak se jeji dějiny odehrávaji na úrovni žánru, tedy v modifikacích žánrových, vzniku nových žánrů a mizeni starých“ (s. 113). To však jsou už hodně staré, standardní myšlenky a jistě

5 Wellkovy náběhy $\mathrm{k}$ tomu, co později vyložil až v USA, jsou pozorovatelné již v jeho meziválečných snahách, kdy se utvářela jeho metodologie a pohled na celou sféru filozofie a literární vědy, viz POSPÍŠIL, Ivo ZELENKA, Miloš: René Wellek a meziválečné Československo: Ke kořenuim strukturálni estetiky. Brno: Masarykova univerzita, 1996. 
by se v nich poznal takový Alexandr Veselovskij, kdyby ještě žil. Ale o něm se v knize nedočteme. Své uvažování o lyrice jako žánru utvrzuje autor nakonec takto: „Má teze tedy zní, že široce vytyčený koncept lyriky jakožto žánru napomáhá při uvažováni o krátké narationí poezii..." (s. 114).

V dalších kapitolách se Culler zabývá teoriemi lyriky počínaje Hegelem, rytmem a repeticí, vztahem metra a rytmu, zvuku a opakování, píše o struktuře lyriky („zmapováni““ lyriky, hyperbola, dramatický monolog, rámcování, lyrická přítomnost) a směřuje na materiálu epideiktické lyriky antického Řecka, renesančního sonetu a poezie Williama Wordsworthe a vztahu lyriky k společnosti a ideologii. Zajímavým nasvícením lyriky je Cullerův pohyb od lyrické poezie jako předmětu interpretace $\mathrm{k}$ lyrice jako rituálu, tedy rytmu, invokaci a zvukovým vzorcům. Zde se Culler protíná, i když v jiném gardu, s poslední knihou Pavla Jiráčka (1955-2020), českého versologa, jenž ji dokončil těsně před svou smrtí. ${ }^{6}$ Podívejme se na jeho čerstvou knihu jako paralelu ke Cullerově koncepci lyriky podrobněji.

Jeho opus magnum přišlo poté, co na Masarykově univerzitě obhájil disertaci na téma Příspěvek k emotivni sémiotice českého verše (1992) a co mu HOST vydal hned tři knihy. Pavel Jiráček vystudoval bohemistiku a romanistiku na Filozofické fakultě tehdejší brněnské Univerzity J. E. Purkyně (nyní Masarykova) a působil na různých fakultách včetně pražské Filozofické fakulty, ale nakonec se pro něho trvalé místo na našich odpovídajících akademických pracovištích - včetně jeho vlastní alma mater - nenašlo. Patřil k špičce moderní české versologie, tedy k naprosté špičce jako důstojný nástupce Miroslava Červenky, ale i jiných. Prorážel - jak rád a často říkám - boční okno k pochopení lyrické poezie a jejího prostoru jako vskutku multidisciplinárního zkoumání, vrátil lyrice její původní smysl a otevřel nové perspektivy a pole zkoumání. Jeho první kniha Lyrický rytmus: o spojeni zvuku a smyslu ve verši (2007) nevznikla na zelené louce; byla spojena s podobnými typy bádání v minulosti, na něž

6 JIRÁČEK, Pavel: Od slov k lyrickému vědomí. Středoevropské centrum slovanských studii. Brno: Jan Sojnek - Galium, 2020 . navazuje, ale už zde sahala po jiných výšinách a kontextech. Těch autor dosáhl v další knize Význam a subjektivita v lyrice: kognitivni struktury v lyrické préedstavě (2008), v níž se nechal vést a inspirovat kognitivní vědou, což vrcholí v třetí knize Kognitivní interpretace českého verše: v rytmických souvislostech metrické teorie Miroslava Červenky (2009). Jeho spojení konceptuálních prostorů lyriky, lyrického subjektu a především podoby rytmu a lyrického slova nasvítilo problematiku lyrické poezie jinak. Jiráček vycházel z konkrétních lyrických básní a mezi jeho „materiálem“ najdeme básně Otokara Březiny, Vladimíra Holana, Josefa Hory, ale také Karla Hynka Máchy, Bohuslava Reynka, Jana Zahradníčka nebo Jana Skácela, ovšem, i Paula Verlaina (romanistické školení se nezapře). Jeho nová kniha připravená do tisku s názvem Od slov k lyrickému vědomi (2020) se skládá ze čtyř kapitol a řady př́loh, v nichž autor demonstruje své experimenty, jež dokládají jeho teze vyložené v předchozím textu: jádrem je slovo v lyrické poezii, vnímání existenciálně prostorového rytmu slabik v lyrických slovech, existenciálně prostorový rytmus blízkosti v lyrických slovech. Již v první kapitole analyzuje pojem rytmus od jeho původního řeckého významu „proud“ v úvahách několika filozofư, kteří smysl slova posouvali a modifikovali až k rrímskému pojetí, které k pohybu přírodnímu připojuje i pohyb vyvolaný činností člověka (Bohumil Nuska). Opíraje se o řadu výroků filozofů, estetiků, „rytmologů“ apod. koncipuje Jiráček své prostorové pojetí lyriky, kde nesmí chybět reflexe o Leoši Janáčkovi, „kdo celý svưj život pozorně naslouchal projeviom subjektu v reči, byl Leoš Janáček. Všude, kde se pohyboval, sbiral drobné a nahodilé zápisky rytmického a melodického spádu lidské mluvy, které nazýval nápěvky mluvy“ (s. 11). Jiráček navazuje na pozdní úvahy M. Červenky o fikčním světě lyrické básně. Uvádí také práce Marie Kubínové, která „také pripomněla propojeni entit vnějšího světa s jejich prožitkovým smyslem, kterév lyrické básni dává sloviom pocitovou atmosfé$r u$, kouzlo zvláštni , srostlosti a časové nerozlučnosti reálné věci a slova. Yves Bonnefoy prohlubuje obdobná pozorováni o básnickou zkušenost a vidi počátek básnického slova pokaždé, když v jazykovém diskursu setreseme nadvládu pojmových artikulaci (zobecněni, 
abstrakcí), které nás vyzývaji, abychom zapomněli, že jsme živé bytosti zde a nyni, na omezený čas, abychom někomu básnickým slovem naopak řkeli právě něco, co souvisís potřebami konečnosti, s fakty jeho náhodného, ale reálného údělu“" (s. 18).

Autor spojuje prostor básně s existenciální dimenzí, uvažuje o rytmu jako organizaci pohybu signifikantů, přemýšlí o vztahu rytmu a subjektu („Kolik subjekti, tolik rytmu nebo kolik rytmi̊, tolik subjektů?“), láká ho existenciální prostorovost slabik v českých lyrických slovech, mluví o světlé a temné prostorovosti slabik. Myslím, že v jistém smyslem jádrem jeho výkladu je čtvrtá kapitola $L y$ rická báseň jako $2 \mathrm{D}$ obraz vědomí lyrického subjektu, zejména hned první část, konkrétní analýzy Dläžděni $2 D$ obrazů lyrického vědomi slabikami a slovy či slovnimi spojenimi ve třech Hrubinových prekladech Verlainozy básně Chanson d'automne. Řada úvah by zněla zdánlivě spekulativně a př́liš abstraktně, kdyby nebyly doprovázeny experimentální, verifikační přílohou na konci této rozsáhlé, ale hutné práce. Jsou to Psychosémantický test na výzkum vnimáni existenciálně prostorového slabičného rytmu v českých slabikách, Třicet lyrických představ, 1264 českých slabik, Test na výzkum vnimáni existenciálně prostorového slabičného rytmu v českých slovech, Test na výzkum vnímáni existenciálně prostorového výpovědniho rytmu slov, Výzkumný soubor triceti čtyr veršouých lyrických predstav (slova a slovni spojení), Dláždèni $2 D$ obrazů lyrického vědomi ve třiceti empiricky zkoumaných lyrických predstavách. Spojení subjektu a rytmu, rytmu a prostoru, prostorový charakter slabik, v lyrických slovech je u Jiráčka, jak stále ukazuje, omezen českou lyrikou, ale celá koncepce je využitelná jinde, je jen otázka, jak to teoretici verše vymyslí a do jaké míry lze přijmout Jiráskovy premisy ve vztahu k jinému jazykovému materiálu. Problematika je to složitá, a proto se autor nemůže vyhnout metaforickému vyjadřování, které však současně explikuje již zmíněnou sítí testů - prozkoumal toho hodně, a jeho úvahy tak mají i významný kvantitativní, materiálový podklad. Řekl bych, že Jiráčkova kniha je „nové slovo“ ve výzkumu české lyriky a lyriky obecně: dokládá, kam se česká teorie verše posunula od proslulých brněnských versologických sborníků z konce šedesátých let 20. stoletî - v osobnosti Pavla Jiráčka se Brno znovu stalo - alespoň na jistou dobu centrem tohoto myšlení.

Zajímavé je, že Jiráček Cullerovu knihu neuvádí v seznamu literatury, i když vyšla anglicky pět let před touto knihou a vlastně těsně před jejím dokončením. Jdou opravdu paralelně, ale najdou se místa průniku, zejména v základním Cullerově pojetí rituality lyriky, v lyrice jako rituálu, tedy rytmu, invokaci a zvukových vzorcích. I když se Jiráček neomezuje jen na českou poezii, je to přece jen jiný materiál - jazykový, literární a obecně kulturní bariéra je to, co omezuje, limituje různé teorie, nehledě na snahu autorů, interpretů a překladatelů. Problémem českého překladu Cullerovy knihy, který je jinak obdivuhodný, je terminologie, ale možná se mýlím a ty posuny se v české versologické tradici prosadí. Vydání svazku v edici Studia poetica je dobrým krokem a v jistém smyslu i reprezentativním vykročením. Zajímavé je setkání dvou knih, které jsem k recenzi na Cullera záměrně připojil, jako by ze dvou odlišných myšlenkových světů, jež jsou si však přesto blízko.

$7 \quad$ Viz blok o ruské poezii a versologii v čas. Novaja rusistika 1, s. 5-66; viz naši studii o brněnské versologické škole Tradicii brnenskogo stichovedenija i specifike russkoj poezii. Novaja rusistiska, 2009, č. 2, s. 55-65.

prof. PhDr. Ivo Pospíšil, DrSc.

Ústav slavistiky

Filozofická fakulta, Masarykova univerzita

Arna Nováka 1, 60200 Brno, CZ

ivo.pospisil@phil.muni.cz

Toto dílo Ize užít v souladu s licenčními podmínkami Creative Commons BY-SA 4.0 International (https://creativecommons.org/licenses/by-sa/4.0/legalcode). Uvedené se nevztahuje na díla či prvky (např. obrazovou či fotografickou dokumentaci), které jsou v díle užity na základě smluvní licence nebo výjimky či omezení príslušných práv. 